\title{
Results concerning the Reduction of Academic Studies Abandonment as an Outcome of Activities Carried Out in the Laboratory for Entrepreneurial Education and Training
}

\author{
Ioan Constantin Rada ${ }^{1, *}$, Liliana Doina Măgdoiu ${ }^{1}$, Anca Păcală², Ioana Carmen Rada ${ }^{2}$ \\ 1,1,2 University of Oradea, Oradea, Romania, ic_rada@yahoo.com , lili34ana@yahoo.com , \\ ancapacala@Yahoo.com \\ ${ }^{2}$ The National Bank of Romania, Bihor county Branch, Romania, ioana.rada@bnro.ro \\ *Corresponding author: Ioan Constantin Rada, University of Oradea, Oradea, Romania, Universității street, \\ no. 1, Romania, zip code:410610, Phone number: 0040736377 297, ic_rada@yahoo.com; \\ icrada@gmail.com
}

Keywords: results concerning abandonment, academic studies abandonment, entrepreneurial education and training, vulnerable group, risk of abandonment

\begin{abstract}
Following the historical events in 1989, in Romania, as well as in other countries, poverty and social exclusion have extended. These phenomena have either influenced directly or generated risk factors such as a) institutional factors or b) personal factors that have a great influence on the process of academic studies abandonment in the case of freshmen at the Faculty of Electrical Engineering and Information Technology of Oradea University. However, students with high risk for abandonment can be determined to give up such an intention due to some activities aimed at their entrepreneurial formation and education whereby they are enabled to acquire the necessary skills for a future career. Thus, the existence of a Laboratory for Entrepreneurial Education and Training might provide opportunities that would later contribute to the reduction of the abandonment phenomenon in the case of the vulnerable risk group formed by freshmen at the Faculty of Electrical Engineering and Information Technology, University of Oradea. Research in this respect has already been carried out, for instance: Romania Secondary Education Project ROSE, which is fully funded by the International Bank for Reconstruction and Development, based on the Law no. 234/2015 for the ratification of the Loan Agreement (the Secondary Education Project) between Romania and the International Bank for Reconstruction and Development, signed in Washington on April 17, 2015; these projects are also in line with the strategic objectives of the University of Oradea and with the objectives of the Faculty of Electrical Engineering and Information Technology. The results of reducing the drop out of university studies are obtained through a series of activities carried out in the Laboratory for Entrepreneurial Education and Training.
\end{abstract}

\section{Introduction}

The results of remedial activities lead to the reduction of the abandonment risk in the case of first year undergraduate students who belong to vulnerable groups. The design, the realization, but especially the development of remedial activities in a Laboratory for Entrepreneurial Education and Training, which we consider a tool whereby such activities can be carried out, offer the possibility to achieve results aimed at reducing the risk of abandonment in the case of first year students who are part of vulnerable groups subject to the aforementioned risk. In our view, such activities are also in line with the new managerial and economic mechanisms designed to meet the pressing needs of humanity. The necessity to find new tools that can reduce the risk of abandonment of university studies in the case of students belonging to vulnerable social groups is part of the new managerial and economic mechanisms, generated primarily by the existence of poverty and social exclusion. The concepts of poverty, social exclusion, entrepreneurship education and training, remedial activities, as well as the tools aimed at reducing the risk of abandonment, have already been 
addressed and discussed by us in several papers that have either been published or are in the course of publication. These are as follows: „Managers and Economist Engineers in the Development of the Social Economy” (Rada, Măgdoiu, 2013); „The Initial and the Ongoing Training of Economist Engineers as Human Resources of the Labor Market” (Măgdoiu, Rada, 2013); „Managers and Economist Engineers between the Social Responsibility of Oil Corporations and the Development of Social Economy” (Măgdoiu, Rada et al., 2014); „Managers and Economist Engineers between Social Economy Development and Obtaining Profit” (Măgdoiu, Rada, 2014); „Forms of Communication and Strategies adopted by Managers and Economist Engineers in the "BLACK SWAN" Situation of Social Economy” (Rada, Măgdoiu, 2016); „The Antifragile of Decisions Adopted by Managers and Economist Engineers Working in the Sector of Vulnerable Groups' Social Economy” (Măgdoiu, Rada, 2016); „Managers and Economist Engineers between the Sociology of the Elites and the Social Economy of Vulnerable Groups" (Rada, Măgdoiu, et al., 2016); "The Contribution of Professional Associations in Romania to the Prevention of Poverty and Exclusion by Developing Social Businesses. Part I" (I.Rada, Măgdoiu \& C.Rada, 2017), "The Contribution of Professional Associations in Romania to the Prevention of Poverty and Exclusion by Developing Social Businesses. Part II " (I.Rada, Măgdoiu \& C.Rada, 2017), "The Contribution of Managers and Economists Engineers' Social Businesses in Reducing Unemployment in Romania” (I.Rada, Măgdoiu \& C.Rada, 2017), as well as „Financing the Social Businesses of Managers and Economist Engineers from Romania” (I.Rada, Măgdoiu \& C.Rada, 2017), „Instrument Aimed at Reducing University Studies Drop-out” (Rada, Măgdoiu, et.all.,2017), „The Importance of the Laboratory for Entrepreneurial Formation and Training In Reducing the Abandonement of Studies” (Măgdoiu, Rada, et.all., 2017).

Of course, we first investigate what are the remedial activities and how these should be carried out under the conditions of the existence of the risk elements; next we focus on the results of the expected remedial activities, which will facilitate the reduction of the risk of abandonment. Based on our previous studies, we have found that specialists from universities (professors, researchers, etc.), in addition to their professional and transversal competences, must be able to understand and accept the status of social activists, i.e. not to hesitate to assume the social role required to solve a social problem, such as university abandonment [1]. "The only thing we have to do is to free them from the preconceived ideas that put profit at the heart of any business, ideas that have been inoculated through our faulty economic theory" [1].

Of course, we need to think about how to financially support such activities and create the tools for their development, respectively the Laboratory for Entrepreneurial Education and Training. Even if development eventually leads to prosperity, the conduction of remedial activities in the Laboratory for Entrepreneurial Education and Training, focusing on the target group or the vulnerable group of students at risk of abandonment, cannot be achieved without funding. It is known that success in this regard is also hampered by the lack of income and insufficient consumption, by the lack of opportunities, as demonstrated by Marian Preda (2007) [2], especially in his work entitled "European Welfare Policy - Squaring the Welfare Cycle "[3].

Next, the intermediary stages of the logical plan will refer to „gathering and analyzing relevant data” [4].

\section{Method}

We believe that, from among the multiple existing research methods, the case study, with its advantages and disadvantages, as demonstrated by Robert K. Yin (2005) [4], is the most appropriate one for the case we have in view. Since the initial questions are of the „how” and „why” type, we can have no total control on events and our intention as regards the results and remedial activities depends on the human factor, which is a subjective one; the resources necessary for the management and implementation of remedial activities are human resources.

\subsection{Study questions}

Taking into account the recommendations of Robert K. Yin (2005) [4] we have formulated the following questions: 
- What are the expected outcomes of remedial activities conducted in the Laboratory for Entrepreneurial Education and Training (LEET), activities that are aimed at reducing the abandonment of academic education by students who are part of vulnerable social groups, during the first years of bachelor studies at the Faculty of Electrical Engineering and Information Technology of Oradea University?

- How do the remedial activities take place with the students who are identified as being at risk of university abandonment, due to a) the institutional factors and b) the personal factors, at the "Faculty of Electrical Engineering and Information Technology" of Oradea University?

- How do results of remedial actions work on the expectations of the target group of students with social problems and at high risk of abandonment?

The first question is about the expected results of the remedial activities performed in the LEET at the Faculty of Electrical Engineering and Information Technology of the University of Oradea, aimed at allowing students at risk of abandonment to continue their studies and be able to practice in the academic profile they have chosen. It represents the first part of our research, the primary variable, and the answers to the following questions are the remedial activities that need to be carried out in the LEET in order to either obtain the expected results or generate solutions, the latter being considered the secondary variable.

\subsection{Hypothesis}

In the research design we will continue with the following component, which is the hypothesis.

The working hypothesis: If the remedial activities carried out with students at risk of university abandonment are determined by: a) the institutional factors and b) the personal factors at the Faculty of Electrical Engineering and Information Technology, at the University of Oradea, then the expected results can be obtained following the remedial activities within the Laboratory for Entrepreneurial Education and Training, which result in reducing the abandonment risk in the case of students belonging to vulnerable social groups during the first years of bachelor studies at the Faculty of Electrical Engineering and Information Technology of the University of Oradea.

\subsection{Analysis units}

According to Robert K. Yin (2005), the third component of the research design "is related to the fundamental problem of defining the case" [4] and targets at the analysis units. This section must be in two columns.

\subsubsection{The primary analysis unit}

It includes the expected results of remedial activities carried out in the Laboratory for Entrepreneurial Education and Training, which will prove efficient in reducing the dropout of first year students who are part of vulnerable social groups, enrolled in the cycle of bachelor studies at the Faculty of Electrical Engineering and Information Technology, of the University of Oradea.

\subsubsection{The context analysis unit}

The following analysis unit refers to the context that generates the existence of the case, namely the conduct of remedial activities with the students at risk of university abandonment, determined by: a) institutional factors and b) personal factors, identified at the Faculty of Electrical Engineering and Information Technology at the University of Oradea.

\subsubsection{The embedded analysis unit}

The analysis unit embedded in the study describes how the results of the remedial actions work on the expectations of the target group consisting of students with social problems at high risk of abandonment

\subsubsection{Linking data to hypotheses}

The research design explains the linking of hypotheses to data. In fact, it is an anticipation of the data analysis stage. The idea of linking hypotheses to data in our study will follow the "mixed model" [4]. The data and information we have used has been obtained from documents, archives, best practices, direct observation, participatory observation. This stage has then been followed by examining, classifying and testing the evidence, paying particular attention to objectively presenting all the evidence, taking into account the exploitation of alternative interpretations. According to the principle of logic, we must follow successively the evidence that expresses the explicit links 
between the data collected, the questions raised and the conclusions reached.

Data obtained from the literature, texts of various documents, direct observation have been used for the remedial activities carried out in the Laboratory for Entrepreneurial Education and Training, aimed at allowing students with a risk of abandonment to continue their studies and finally be able to practice in the academic profile they have enrolled in; the activities referred to above include: Counseling activities with the following sub-activities: training and personal development, mentoring and support through tutorials, professional counseling and career guidance; Applying, in simulated enterprises, the knowledge and skills acquired by students at their university education profile; Deployment of remedial programs; Renovation and endowment of the education and training laboratory; Management activities and implementation activities conducted as part of a research project generated by the existence of institutional and individual risk factors leading to university abandonment; how the research results work on the expectations of the target group of students with social problems, who also present a high risk of academic studies abandonment.

Data have been obtained from: the statistical situations of the University, of the Faculty and of the Ministry of Education; documents of the EUROSTAT sites; the National Institute of Statistics of Romania; the texts of different documents; direct observation. Data has been evaluated with the view of highlighting the risk factors that determine a) institutional factors and b) personal factors leading to university abandonment, namely: Failure to meet student expectations; the capacity of the students, enrolled in the first year at the Faculty of Electrical Engineering and Information Technology, at all specializations, to adapt their knowledge to the content of either the study programs or the teaching processes, to the learning requirements and to student life; The concordance between the offer of the faculty and the students' expectations regarding the content of the curricula or the teaching-learning processes makes clear the contextual links of the existence of the aforementioned factors and the results obtained by means of activities carried out in the Laboratory for Entrepreneurial Education and Training, aimed at helping students continue their studies so that they can practice in the academic profile they have chosen; it also demonstrates how research results work on the expectations of the target group of students with social problems and high risk of abandonment.

The results of the research act on the expectations of the target group of students with social problems and high risk of abandonment by: ensuring the students' access to new content in the respective field of study; familiarization of students with pedagogical norms appropriate for the university level (way of deployment and contents of pedagogical activities, evaluation forms, etc.); teachers' highlighting the practical applicability of the theoretical notions taught in students' future professional life; the explicit correlation of the academic training of students with the professional skills necessary to practice an occupation required on the labor market; clear explanation/demonstration of how students can economically exploit certain knowledge they acquire in college; developing students' horizontal competences (entrepreneurial and social/civic competencies). Remedial theoretical knowledge gaps and learning abilities of students from the first year; Applicative teaching of theoretical/scientific notions; Creating opportunities for students to use economic and professional knowledge and skills acquired in college; Professional counseling and career guidance; The development of the spirit of initiative (both entrepreneurial and social) of the students of the first year clearly demonstrates the links between the existence of the risk factors that determine a) the institutional factors and b) the personal factors leading to the university abandonment in the first year of studies and the necessity for the Laboratory for Entrepreneurial Education and Training, in order to enable young students continue their studies to be able to pursue the academic profile they are enrolled; the study also focuses on how research results work on the expectations of the target group of students with social problems and high risk of abandonment.

\subsubsection{Criteria for data interpretation}

This is the last component of the research design and it anticipates the data analysis stage. The goal is to perform a quality analysis, which requires special attention for all the evidence. Evidence must be presented objectively, showing interest in exploring interpretations. We will use the combined criteria for interpreting the findings, generally using the logical models where "The 
logical model deliberately stipulates a complex chain of events over time. These are included in repeated cause-effect-cause-effect patterns "[4]. So, the dependent variable from an initial stage "The expected results of remedial activities carried out in the Laboratory for Entrepreneurial Education and Training, aimed at reducing the dropout of students belonging to vulnerable social groups in the first years of undergraduate studies at the Faculty of Electrical Engineering and Information Technology of the University of Oradea" becomes an independent variable at a later stage, i.e. "the development of remedial activities with the students at risk of university abandonment determined by: a) the institutional factors and b) the personal factors identified at the Faculty of Electrical Engineering and Information Technology, of the University of Oradea.

\subsection{Preliminary theories}

The approach to the five components of the research design in relation to the topic of the study represents the importance of preliminary theories. The problem of conceptualization is also encountered at Babbie, 2009, who has argued that the "clarification of concepts is a continuous process in social research" [5]. Of course, we do not claim that we can exhaustively theorize a whole range of potential theories, relevant to our study; therefore we shall call upon the application of: a) "Theories about individuals" [4], i.e. the theories about the development of student as entrepreneurs; b) "Group Theories" [4], i.e. about the vulnerable social groups of students at risk of abandonment; c) "Organizational Theories", i.e. the theories about the setting of the Laboratory for Entrepreneurial Education and Training within the Faculty of Electrical Engineering and Information Technology of the University of Oradea; d) "Societal Theories" [4], such as funding for the implementation of the research project.

The first theorization refers to the primary unit of analysis, i.e. to the expected results of the remedial activities carried out in the Laboratory for Entrepreneurial Education and Training, which might result in reducing the phenomenon of academic studies abandonment in the case of students belonging to vulnerable social groups in the first years of bachelor studies at the Faculty of Electrical Engineering and Information Technology of the University of Oradea.

At the level of the Faculty of Electrical Engineering and Information Technology of the University of Oradea, as grant beneficiary, the expected results imply improvements in the following areas:

(1) Access and motivation of disadvantaged students to quality education through education and training as entrepreneurs in their fields of study.

(2) Ensuring the increase of the graduation degree at the end of the first year of higher education;

(3) Determining a high level of collaboration and relations at the university level, between the involved actors (professors, auxiliary staff, students, etc.), by improving both vertical and horizontal communication means;

(4) Improving the quality of teaching/learning processes, with an emphasis on student-centered teaching and the development of entrepreneurial socio-emotional skills (entrepreneurship, social entrepreneurship, political entrepreneurship, entrepreneurship in research, intra-entrepreneurship), so as students might become creators of jobs, rather than jobseekers in their field of study;

(5)Promotional marketing campaigns concerning the educational orientation of high school students regarding the existing options and opportunities for continuing studies at the University of Oradea.

These expected results will be achievable only by observing fundamental principles such as:

- Equal access of all eligible participants to information regarding the purpose, activities and requirements of the Grant Scheme;

- Geographical coverage, all Faculties in the University being eligible;

- A comprehensive approach, involving all those interested in the university level, adapting the dissemination of information to different actors - the university and faculty leadership, the Career Counseling and Career Guidance Staff and the Teaching Staff Training Departments/Education and Psychology faculties, student associations, teachers, students, etc., in order to reduce the abandonment rate in the first year of higher education;

- Transparency and fairness in the evaluation of sub-project proposals, by providing funding 
according to a methodology agreed by the donor and which is publicly disseminated;

- Responsibility and efficiency in project management and in the use of funds provided in accordance with the applicable legal and contractual provisions, including those relating to environmental protection; and

- Transparency and fairness, in compliance with the provisions of the Anti-Corruption Guidelines and other relevant regulations. The following theory, without which it is not possible to obtain the above mentioned results, is the one formed around the contextual analysis unit, i.e. the remedial activities carried out with the students at risk of university abandonment determined by: a) the institutional factors; b) the personal factors at "Faculty of Electrical Engineering and Information Technology" at the University of Oradea.

In order to achieve the objectives proposed as part of the grant, the following implementation activities will be carried out:

(1) Putting into practice remedial programs

(a) Assessing the needs of disadvantaged students from the first year of studies as regards remedial programs

(b) Elaboration of remedial programs after evaluation

(c) Operationalization of remedial programs

(d) Analysis of the results obtained after the deployment of remedial programs

(2) Training and personal development activities

(a) Evaluating the qualities of an entrepreneur together with students who are identified as having a high-risk of academic studies abandonment

(b) Starting a business

(c) The Road from Idea to Opportunity

(d) Preparation of the business plan

(3) Guidance and support (tutorial)

(a) Evaluation, by the tutor, of the need for academic guidance of students at risk of abandonment in the first year of university studies

(b) Conducting the plan and the measures necessary for helping students at high risk of abandonment in the first year of academic education, to get used with the requirements of the university life and form their moral and intellectual character

(c) Tutor activities: adapting knowledge to the objective reality (making information accessible to students); group monitoring; analyzing the group's activity; team work; identifying and understanding individual characteristics; deepening needs analyzes;

(d) Evaluation of the quality and effects of tutoring

(4) Professional counseling and career guidance

(a) Career counseling activity

(b) Education and training activity for the entrepreneurial career

(c) Career planning activity

(5) Workshops in the fields of study (specializations)

(a) Workshop on Business Entrepreneurship

(b) Workshop on Social Entrepreneurship

(c) Workshop on Political Entrepreneurship

(d) Workshop on Entrepreneurship in Research

(e) Workshop on intrapreneurship

\section{Collecting evidence}

Synthetic budget for developing remedial activities in order to obtain results: 
Table 1. Synthetic Budget [7]

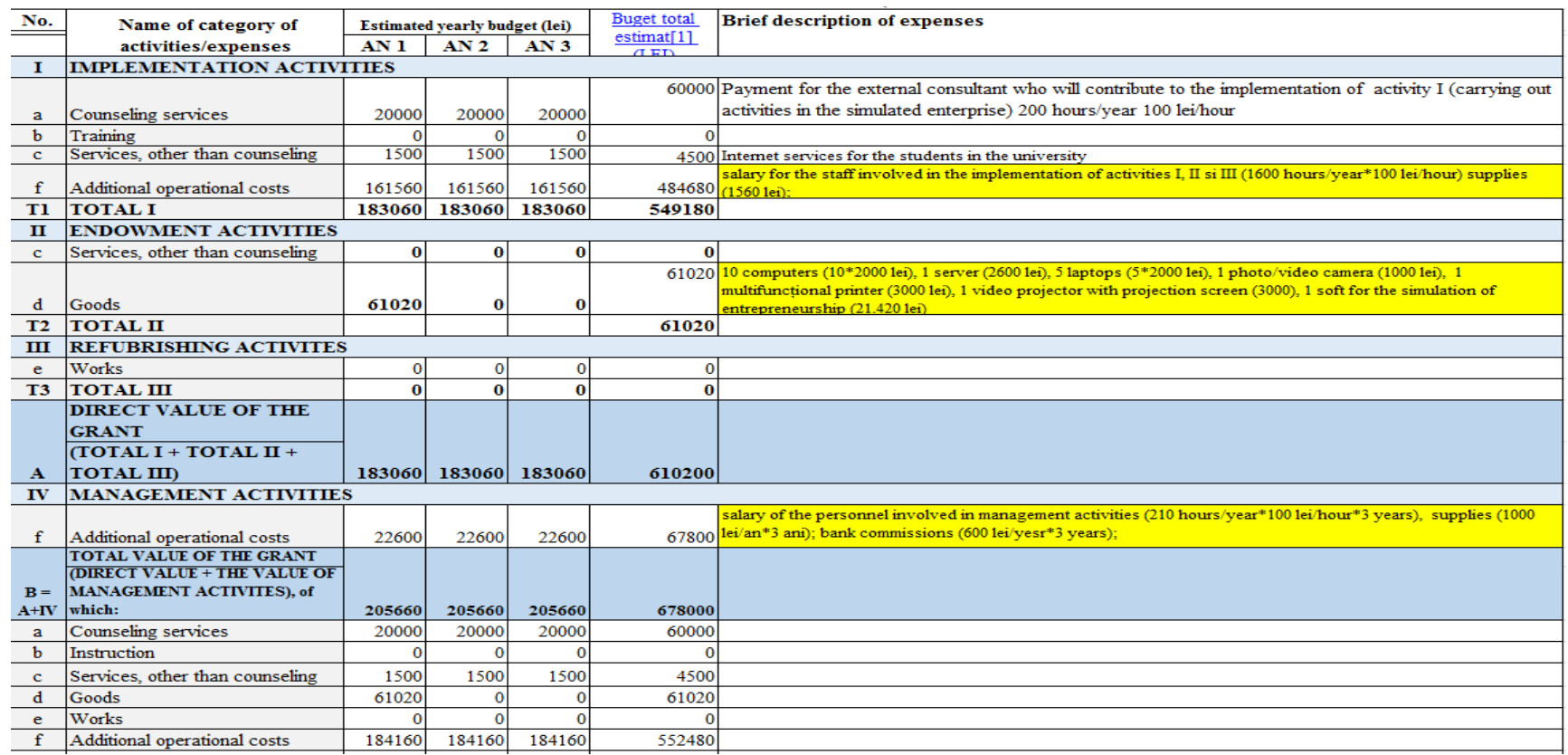

Source: The author's proposal for the budget necessary in Instrument Aimed at Reducing University Studies Drop-out, Proceedings of International Conference on 15th International Conference on Future Trends in Engineering and Business (May 26-27, 2017), Organized by International Organization of Scientific Research and Development (IOSRD), Chennai, India, 2017.

\section{The analysis of proofs}

The results obtained after completing remedial activities in the Laboratory for Entrepreneurial Education and Training will lead, according to our analysis, to the following impact factors:

Source: The author's proposal for the budget necessary in Instrument Aimed at Reducing University Studies Drop-out, Proceedings of International Conference on 15th International Conference on Future Trends in Engineering and Business (May 26-27, 2017) , Organized by International Organization of Scientific Research and Development (IOSRD), Chennai, India, 2017.

Table 2 Impact Indicators after the Implementation of the Research Project [7]

\begin{tabular}{|c|c|c|c|c|c|c|c|c|c|c|c|c|}
\hline \multirow[b]{2}{*}{ Description } & & & \multirow{2}{*}{\multicolumn{2}{|c|}{$U M$}} & \multirow{2}{*}{\multicolumn{3}{|c|}{ Reference value }} & \multicolumn{5}{|c|}{ Proposed values } \\
\hline & & & & & & & & \multicolumn{2}{|c|}{\begin{tabular}{l|l} 
1st \\
YEAR
\end{tabular}} & $\begin{array}{l}\text { 2nd } \\
\text { YEAR }\end{array}$ & \multicolumn{2}{|c|}{$\begin{array}{l}\text { 3rd } \\
\text { YEAR }\end{array}$} \\
\hline \multicolumn{3}{|l|}{ Rate of promotion after the 1st year of study at bachelor level studies } & \multicolumn{2}{|c|}{$\%$} & \multicolumn{3}{|c|}{$82,3 \%$} & \multicolumn{2}{|c|}{83,3} & 84,3 & \multicolumn{2}{|c|}{84,5} \\
\hline \multirow{4}{*}{ Description } & \multicolumn{12}{|c|}{ Proposed values } \\
\hline & \multicolumn{4}{|c|}{ lst YEAR } & \multicolumn{4}{|c|}{ 2nd YEAR } & \multicolumn{4}{|c|}{ 3rd YEAR } \\
\hline & \multicolumn{2}{|c|}{ Ist semester } & \multicolumn{2}{|c|}{$\begin{array}{l}\text { 2nd } \\
\text { semester }\end{array}$} & \multicolumn{2}{|c|}{ lst semester } & \multicolumn{2}{|c|}{$\begin{array}{l}\text { 2nd } \\
\text { semester }\end{array}$} & \multicolumn{2}{|c|}{$\begin{array}{c}\text { lst } \\
\text { semester }\end{array}$} & \multicolumn{2}{|c|}{$\begin{array}{l}\text { 2nd } \\
\text { semester }\end{array}$} \\
\hline & $F$ & $M$ & $F$ & $M$ & $F$ & $M$ & $F$ & $M$ & $F$ & $M$ & $F$ & $M$ \\
\hline Total number of students that have benefited from support & 45 & 55 & 45 & 55 & 45 & 55 & 45 & 55 & 45 & 55 & 45 & 55 \\
\hline $\begin{array}{l}\text { Total number of students prone to risk that have benefited from } \\
\text { remedial activities as part of the grant }\end{array}$ & 15 & 25 & 15 & 25 & 15 & 25 & 15 & 25 & 15 & 25 & 15 & 25 \\
\hline $\begin{array}{l}\text { Number of students in a situation of risk who benefited from } \\
\text { coaching and personal development activities, tutorship and career } \\
\text { orientation, etc. }\end{array}$ & 15 & 25 & 15 & 25 & 15 & 25 & 15 & 25 & 15 & 25 & 15 & 25 \\
\hline $\begin{array}{l}\text { Number of students in a situation of risk that have benefited from } \\
\text { workshops in their fields of study (specializations) }\end{array}$ & 15 & 25 & 15 & 25 & 15 & 25 & 15 & 25 & 15 & 25 & 15 & 25 \\
\hline
\end{tabular}

\section{Conclusions}

Achieving the expected results by conducting remedial activities in the Laboratory for Entrepreneurial Education and Training, aimed at students from vulnerable social groups exposed to the risk of university dropout in the first year of study ensures the reduction of this form of 
abandonment.

Through the implementation of the research project, the overall objective of this research is achieved: the development of activities in the Laboratory for Entrepreneurial Education and Training, as a tool that can reduce the risk of abandonment in the first year of study, in the case of students belonging to vulnerable groups subject to the risk of academic studies drop-out.

\section{References}

[1] Yunus, M. (2010). Building Social Business: The New Kind of Capitalism that Serves Humanity's Most Pressing Needs, United States, Public Affairs a member of the Perseus Books GroupBabbie, E. (2009). The Practice of Social Research, Eleventh Edition 0495093254Duncan, G. J., \& Brooks-Gunn.

[2] Preda, M. (2007). The Romanian Social Policy Between Poverty and Globalization (Politica socială românească între sărăcie și globalizare), Iași: Polirom.

[3] Buzducea, D. (2013). The Social Economy of Vulnerable Groups (Economia social a grupurilor vulnerabile), Iași, Polirom.

[4] Yin, R.K. (2003). Case Study Research. Design and Methods, Sage Publications, Thousand Oaks, London, New Delhi.

[5] Preda, M. (2002). Social exclusion (Excluziunea socială), în L.M.Pop, Dictionary of Social Policy (Dicționar al Politicii Sociale), București, Expert

[6] Ghenea, M. (2011). Entrepreneurship: the Path from Ideas to Opportunities and Success in Business (Antreprenoriat: drumul de la idei către oportunități și success în afaceri), București: Universul Juridic.

[7] Rada, I.C., Măgdoiu, L.D., et. all., Instrument Aimed at Reducing University Studies Drop-out, Proceedings of International Conference on 15th International Conference on Future Trends in Engineering and Business (May 26-27, 2017), Organized by International Organization of Scientific Research and Development (IOSRD), Chennai, India, 2017. 